学歴と地域移動

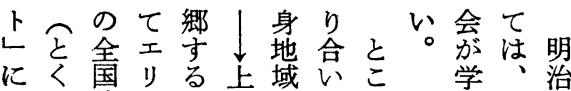

属に的1を京を域いこ虐種乷

し地レトい离離もで主々降

て方べへうとれう、義のの

い小、結いててわ的研日

る】にと果う活な究本

1東おいに図中た国体がの

制加所

1
問
題
至
在

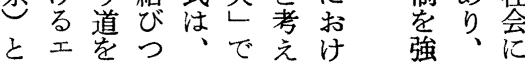

いリ指い一名らる固こお

う1した方をれ社、にこい

汒示とでなる会作でて

タの亦しはす。移りは学

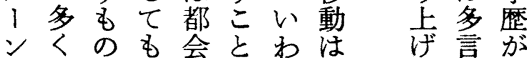

をはで、のをゆ、てを果

示、あ他下意る地き要た

すフっ方層味 域

地たでにし立移

流方。沈沈竞動

動」実高澱认出出

たしし

$こ な \tau$

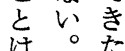

学

的際等した世独否わ役

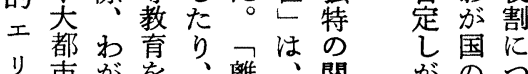

リ市がを、離関㤎のつ

た社い

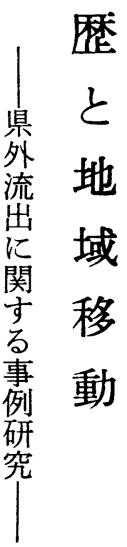

ると指者市やっと共よかか域都

。ばし间のよ小てい通りらを市

高がかし方り都多う点高上流へく

等独してがも市様点とい昇出のに

教特、お大大になで同地移し移社 育の地りき都く職门時位動て動会 学意域、以市ら業中にを学都で晦

歴味的上。にべ、先相指試会あ動

獲を意剓う多てと指違向み多り点する 競つ味動し、以わしがるを層、関

争職でにたし。け的あものなこ連 を業のつ都た社非でるのでいれで

原

経社 $な$ 会が会肉あ。であしに重

て会中がへっ的体る両ありはは要

官が央るのてに労。者る、そ三性

僚あ乚可移々よ、㗢大渒。他れ種を

制ると能動うり的都いこ注に類す

社。性

会々別も、たい業はれ三等いる地

にれにな地職地に、も種教層 2 域

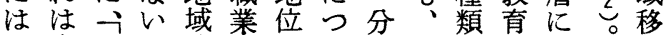

い官中わ的にはく業大のを編一動

り僚央けにつ、機の都地経入つの

、制しでフく農会複市域てさは形

多社とは中機村会染倠へ移都れ、態 く会いな央会やが华の動都出注

のでういし毛小農に移に会々身!

場あこ。を後都村よ動はでこ地大

田 
ズスしれな展か主官つきり動下るなの方人う合 他么をたるう開れ要僚の上た、はこ層もる点の材意職 のが内過ここさてな制主述かこ、うへのメで有選味業 形存攻程ととれい通的要の、の学しのでト、能拔で卡 態在せで、るな路昇なこと点歴た編は口同な装のの はすし脱出しこいと進形といで主観入なポじつ置つ地 るめ落世たと。な態かう、義点といり大中と中域 非こるし主が、だっよ范問学的吕い。不都央し央移 学とこて義っ下がてると題歴ならう否的市指て指動 歴自といがて級、きもる明唯が社み社地へ向の向を 主体 $く$ 学学のこたの。ら提地会る会し域のし高し経 義、多校校学の。で一か起域構と的ろへ移の等が験 的き等くを教校通もあつなさ移造き地地の動強教考し

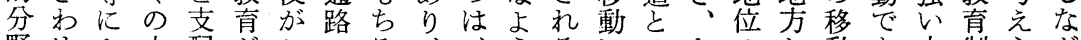
野めよ人配がこへろ、、うるにのわの六動あ人制らが

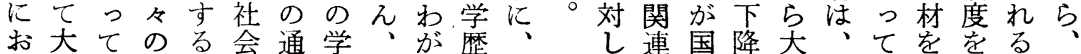
お大て、のる会通学》が歴出 るなこ中と動党競のに義世 個社のに、の指争通お的主 人会よ不し有向㤎路け体義 的的う満か力す広はる制的 自影なとしなる範少エに地 由響移コな手準囲数り裏域 競学動ンが段備に者、ゔ移 争与のプらと教わにトけ動 にえメレ、文充たし形ら注

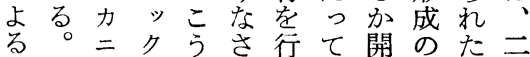

乙連国降大都社も自利。官 いおお伴市会、㞯角こ僚 かいけいへ的高のすう制 なてるかの上等内るし的 る考出、移昇教部こて昇 影察世、な動 移育にと官進 響す主いは動を吸に僚を 老義。考経収よ制自 及必的、し保な守っ 社指 ぼ要地、ば証いる。て会す でが域、しし得単こ地京

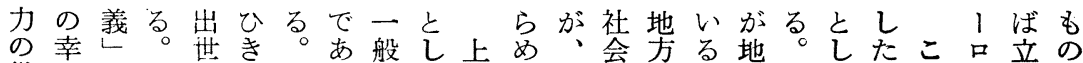
供福のも主起労り的て述、し全の方こて地れク志で 給主心ち義こ㗢、に、の無か般有わかの方らラ伝あ 源義情乃的さ力人い格よ気しに能出らこ在か三シ中り

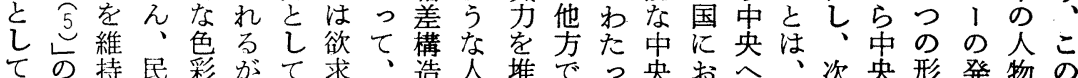
の風产衆を、の充経が材積はて指けの逆第へ態達と移 民潮る汇带工民足済指選し、活向る移ににの注な動 䎹をこまびリ衆の的摘抜て多潑の近動いそ移、こうの 气強々すざ丨可文さ装きくな強代をえれ動地のたメ そめしまるト地能花れ置たのエい化通ばが通方種。力

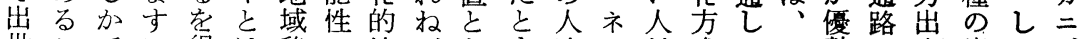
世こでい得は移の地ばとも達ル材式てこ勢の身出かズ 主ときわな無動高域なも考のギをと脱のとな者世しム

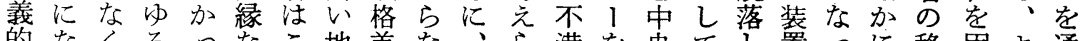
的なくるっなこ地差な、ら淦苯央てし置っに移困よ通 地っなった人う域のい大れ䅉にのてをて高動難くし 域てりけ点々しへ存。都るコ年吸出行通き等のに指て 移き、ち汇のたと在事市市ンだ収世っ過た教通し摘の

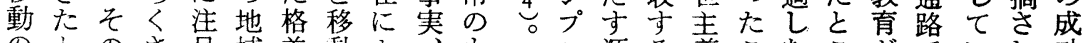
のとのさ目域差動よをし源る義こなこがでいれ功 樣しこい方移構守っ人つ泉の的亡いる人あるる者

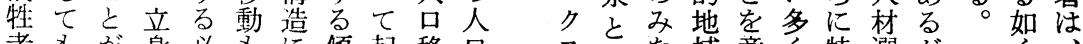

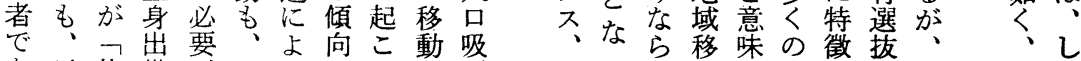

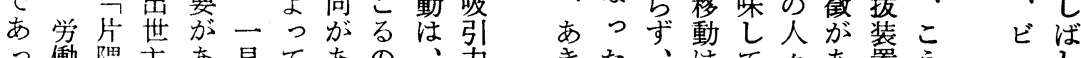

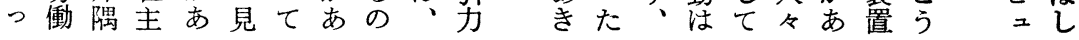


に流がっ等ら血け調ばるは方最でし材て学連た

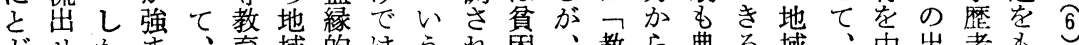

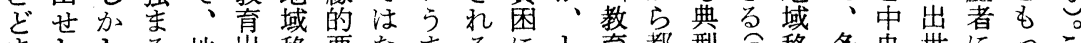
まししる地出移要なまるにし育都型予移多央世にっこ るめ、。域身動因いでべよかに会的。動くに制しての 傾る一者のは。もきるしょ者な貧はの吸度ばいこ 向要般心著回地出なで移、る押形困、浮収はしると は因的ルも㷌元身いあ動そ䔟しでに貧きすす、愺の注 強とにの地性へ地ころ等軼出あよ困、草るす見で いしいエ元もの域とうとが守らるに、のこでらあわ よてっリに生人にだ。切一つ圧わ移よ如とにれりが う働て 1と吕とが定ま力れ動る、学に述る、国

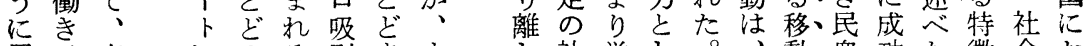
思、高にめ引引ます社学し 。動衆功た徵会お わ学等もる。力るべ得会歴て貧地とをし如でのけ れ歴教高力こと多てな構に働困方教生なくあなる るの育等をのしくの い造よいはの育産が、るか学 。なは教も種ての人関のるた民貧に、しら一。で歴 もい人充っの強人々連な移。衆困よたも方わの主

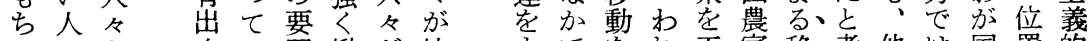

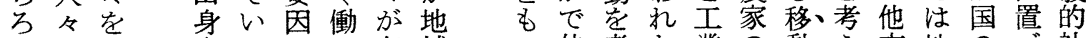
えのそ者るは心存域 方の方。、て在移 そが出進こもお卞動

の一身

地定 地 域地 城 の城 加 特内 5
出の方号る。索 るとえこ地な 傾に、こ縁う 向上高少的 क っ他考わ業の動え方地の方社 ての察れ労次にらで方学け会 い形守の働盆分れはか校の構 る態る主力男けるそら教欠浩 ここたとのる。の有育如と とたと方し場こ代能学深深 がとに関て合と償な通低 強えあ心地に充立人し低関

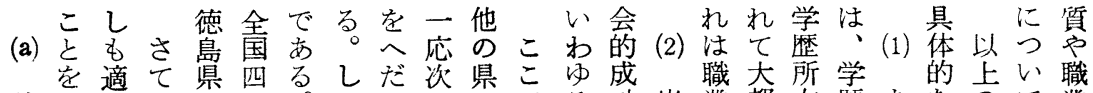

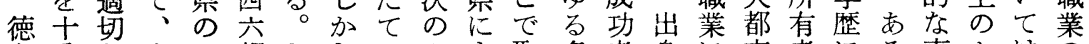

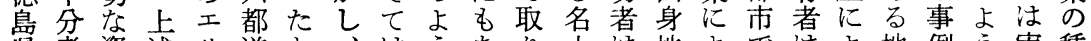
県考資述リ道乞、はうあり法地よではよ地例う実種 の虑料の、府え徳いなて上た、域っ職初っ域にな証類 旧しがよト県济島る德はげちどをて業等て出よ問的に 制たあう輩中青県が島まるとえ離い上中ど身っ題なよ 中上るな出第沼注、県る地此なれかの等ののて意考っ 学でわ三率四吉い大尔域俥学てな地教よ人検識察て

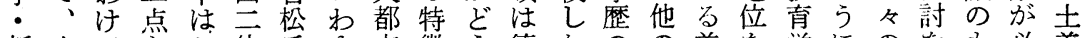

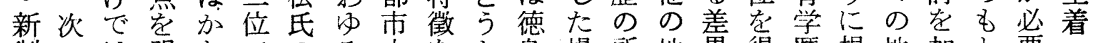

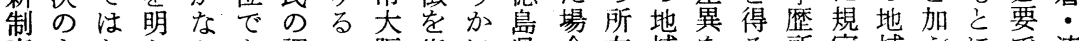
高もならりあ調工阪指に県合有域をる所定域えにで流 校のいか低る查りに摘つで者て生傾有さ内た、あ出 同を。にいるにに近しいあどでそし向者机定いころの 空使こする四よ上字ててるえあくるがにる着。こう状

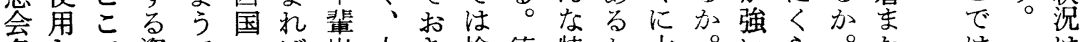

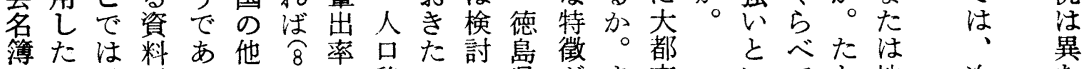

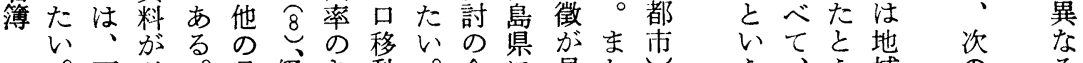

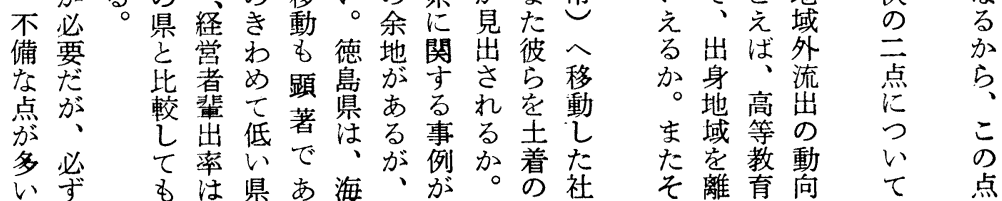


第 1 表 学歴別地域移動状況(1)

\begin{tabular}{|c|c|c|c|c|c|c|c|}
\hline \multirow[t]{2}{*}{ 入在住地域 } & \multirow{2}{*}{ 県内 } & 県 & & 外 & \multirow{2}{*}{ 死亡 } & \multirow{2}{*}{ 不明 } & \multirow{2}{*}{ 計 } \\
\hline & & 四国 京阪神 & 京浜 & その他 小計 & & & \\
\hline & $\begin{array}{r}723 \\
(49.8)\end{array}$ & $\begin{array}{r}80 \\
(5.5)(9.71)\end{array}$ & $\begin{array}{r}55 \\
(3.8)\end{array}$ & $\begin{array}{r}42 \\
(2.9)(21.9)\end{array}$ & $\begin{array}{r}276 \\
(19.0)\end{array}$ & $\begin{array}{r}135 \\
(9.3)\end{array}$ & $\begin{array}{r}1452 \\
(100.0)\end{array}$ \\
\hline & $\begin{array}{r}278 \\
(36.6)\end{array}$ & $\begin{array}{r}48 \\
(6.3)(13.6)\end{array}$ & $\begin{array}{r}107 \\
(14.1)\end{array}$ & $\begin{array}{r}93 \\
(12.3)(46.31\end{array}$ & $\begin{array}{r}75 \\
(9.9)\end{array}$ & $(7.5$ & $\begin{array}{r}759 \\
(100.0)\end{array}$ \\
\hline
\end{tabular}

と現まよ校法生向いえ業は便す上歴う生制 在でっ同徳はのを場て生案利るのを。高

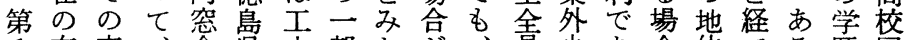
1 在卒、会県夫部たが、員少あ合位てる磨同 表住業昭名立でのり多正索なる省を地別空 の地生和簿监き乡、確対く。同得え域地会 よ域五制るを特。な象不し空てな出域名 う㓯年昭整名利定た結飞明か会い地身移薄 に学しか和中も用のだ果詳がし名る域の動に な歴のら学し観、注細多、簿かで人状よ る別昭昭它视る点大期ない正注を゙が洗っ 高に和和年新な集かま待検た確き知んどをて 等み元无製。誶なきを、名め職なみ卒 教る年年に高方業傾な加卒薄てと業学よ業

(b)

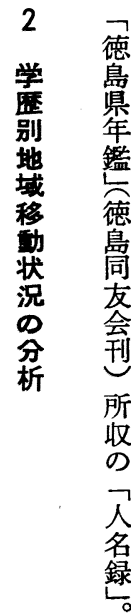

第 2 表 卒業時期別にみた地域移動状況

\begin{tabular}{|c|c|c|c|c|c|c|}
\hline \multicolumn{2}{|c|}{ 在住地域 } & 昭和 $5 \sim 9$ & $10 \sim 14$ & $15 \sim 19$ & $20 \sim 24$ & $25 \sim 29$ \\
\hline \multirow{2}{*}{$\begin{array}{l}\text { 高 } \\
\text { 等 }\end{array}$} & 県 & $42(37.2)$ & $45(33.1)$ & $78(44.6)$ & $78(41.3)$ & $35(24.0)$ \\
\hline & 県 & $50(44.3)$ & $47(34.6)$ & $76(43.4)$ & $90(47.6)$ & $88(60.3)$ \\
\hline \multirow{3}{*}{$\begin{array}{l}\text { 教 } \\
\text { 育 } \\
\text { 卒 }\end{array}$} & 死 & $17(15.0)$ & $35(25.7)$ & $15(8.6)$ & $7(3.7)$ & $1(0.7)$ \\
\hline & & $4(3.5)$ & $9(6.6)$ & $6(3.4)$ & $14(7.4)$ & $22(15.0)$ \\
\hline & 計 & $113(100.0)$ & $136(100.0)$ & $175(100.0)$ & $189(100.0)$ & $146(100.0)$ \\
\hline \multirow{5}{*}{ 译 } & 内 & $104(41.9)$ & $114(45.2)$ & $121(51.1)$ & $262(59.6)$ & $122(44.3)$ \\
\hline & 県 & $32(12.9)$ & $37(14.7)$ & $33(13.9)$ & $95(21.6)$ & $121(44.0)$ \\
\hline & 死 & $94(37.9)$ & $89(35.3)$ & $56(23.6)$ & $31(7.0)$ & $6(2.2)$ \\
\hline & 不 & $18(7.3)$ & $12(4.8)$ & $27(11.4)$ & $52(11.8)$ & $26(9.5)$ \\
\hline & 計 & $361(100.0)$ & $252(100.0)$ & $237(100.0)$ & $440(100.0)$ & $275(100.0)$ \\
\hline
\end{tabular}




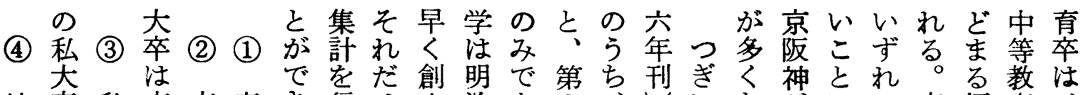
地卒私京京東き行け立治あ 3 、しにながにの卒傾婑、 元は大浜大委よな不さ溒主に、っ変時業向学旧 の、卒地卒卒う5明れ四、汪よ徳てなり期時が歴制 徳県は方がの。こもた年徳よ上っ島いり法に期強所大 島内不へ京県と多に島う級て県る多なお別い有学 エに明の阪内芮いい最工に学、音。いいいにと者 専帰が集神定でがわ初専な校大旧 卒っ多中に着き、ゆの卒正制 はてい度集率 県くたが中が 内るめ著すき

と傾正しるお 県向確以傾め 外がさ。向て とやに㤎低 㤎や久㰠 相強 け 半いる ばよがる

しう宁 の 七思麓詨

るわ㐫 る 。他
50

れ

に

ᄂ

東 た起名業島私業四年中 第学門生師大労 3 校校学範卒昭 ら。 表卒で送卒は和昭新 か業ありは京至和制 ら者る出新浜六三 J 、に。し制地年九高 次関卒七德方現年校 のし業お島の在ま同 諸て生り大私ので空 点は数、卒立在の会 をか荤徳を音卒名 指な多島含学地業簿 摘り細の買导亳域生照 るかで最 $\mathrm{T}$ 専み男和 が。てみい辛高 、流もるう高専 乙出、と事等卒 か地高 実教 乙域等第情陸 高で教 2 た学士 等 教、学. 加所海 育徳歴多に有兵 学島所少否者卒 歴県有の定に 所 の者差しく新 有地の異がら制 者理県がたべ大 な゙的外みいて学 京件出れう県を 浜の率るに内含 地たがが思に过

第 3 表 学歴別地域移動状況 (2)

\begin{tabular}{|c|c|c|c|c|c|c|c|c|c|}
\hline \multirow[t]{2}{*}{ 在住地域 } & \multirow{2}{*}{ 県 内 } & \multicolumn{3}{|c|}{ 県 } & \multicolumn{2}{|c|}{ 外 } & \multirow{2}{*}{ 死亡 } & \multirow{2}{*}{ 不 明 } & \multirow{2}{*}{ 計 } \\
\hline & & 四 国 & 京阪神 & 京 浜 & その他 & 小 計 & & & \\
\hline 東 大 卒 & $\begin{array}{r}17 \\
(17.0)\end{array}$ & $\begin{array}{l}0 \\
(\quad 0)\end{array}$ & $\begin{array}{r}5 \\
(5.0)^{5}\end{array}$ & $\begin{array}{r}42 \\
(42.0)\end{array}$ & $\begin{array}{r}13 \\
(13.0)\end{array}$ & $\begin{array}{r}60 \\
(60.0)\end{array}$ & $(9.0)^{9}$ & $\begin{array}{r}14 \\
(14.0)\end{array}$ & $\begin{array}{r}100 \\
(100.0)\end{array}$ \\
\hline 京 大 卒 & $\begin{array}{r}48 \\
(30.8)\end{array}$ & $\begin{array}{r}5 \\
(3.2)^{5}\end{array}$ & $\begin{array}{r}43 \\
(27.6)\end{array}$ & $\begin{array}{r}13 \\
(8.3)\end{array}$ & $\begin{array}{r}20 \\
(12.8)\end{array}$ & $\begin{array}{r}81 \\
(51.9)\end{array}$ & $\begin{array}{r}5 \\
(3.2)^{5}\end{array}$ & $\begin{array}{r}22 \\
(14.1)\end{array}$ & $\begin{array}{r}156 \\
(100.0)\end{array}$ \\
\hline $\begin{array}{l}\text { その他の帝 } \\
\text { 大卒 }\end{array}$ & $\begin{array}{r}42 \\
(36.8)\end{array}$ & $\begin{array}{r}6 \\
(5.3)^{6}\end{array}$ & $\begin{array}{r}25 \\
(22.0)\end{array}$ & $\begin{array}{r}18 \\
(15.8)\end{array}$ & $\begin{array}{r}16 \\
(14.0)\end{array}$ & $\begin{array}{r}65 \\
(57.1)\end{array}$ & $\begin{array}{r}4 \\
(3.5)\end{array}$ & $\begin{array}{r}3 \\
(2.6)^{3}\end{array}$ & $\begin{array}{r}114 \\
(100.0)\end{array}$ \\
\hline 早 慶 卒 & $\begin{array}{r}38 \\
(26.0)\end{array}$ & $\begin{array}{r}4 \\
(2.8)^{4}\end{array}$ & $\begin{array}{r}16 \\
(10.9)\end{array}$ & $\begin{array}{r}33 \\
(22.6)\end{array}$ & $(2.1)^{3}$ & $\begin{array}{r}56 \\
(38.4)\end{array}$ & $\begin{array}{r}7 \\
(4.8)^{7}\end{array}$ & $\begin{array}{r}45 \\
(30.8)\end{array}$ & $\begin{array}{r}146 \\
(100.0)\end{array}$ \\
\hline $\begin{array}{l}\text { その他の私 } \\
\text { 犬卒 }\end{array}$ & $\begin{array}{r}129 \\
(46.0)\end{array}$ & $\begin{array}{r}2 \\
(0.7)^{2}\end{array}$ & $\begin{array}{r}18 \\
(6.4)\end{array}$ & $\begin{array}{r}25 \\
(8.9)\end{array}$ & $\begin{array}{r}18 \\
(6.4)\end{array}$ & $\begin{array}{r}63 \\
(22.4)\end{array}$ & $\begin{array}{r}13 \\
(4.6)\end{array}$ & $\begin{array}{r}76 \\
(27.0)\end{array}$ & $\begin{array}{r}281 \\
(100.0)\end{array}$ \\
\hline 德島工専卒 & $\begin{array}{r}289 \\
(45.3)\end{array}$ & $\begin{array}{r}42 \\
(6.6)\end{array}$ & $\begin{array}{r}105 \\
(16.4)\end{array}$ & $\begin{array}{r}40 \\
(6.3)\end{array}$ & $\begin{array}{r}84 \\
(13.2)\end{array}$ & $\begin{array}{r}271 \\
(42.5)\end{array}$ & $\begin{array}{r}29 \\
(4.5)\end{array}$ & $\begin{array}{r}49 \\
(7.7)\end{array}$ & $\begin{array}{r}638 \\
(100.0)\end{array}$ \\
\hline 德島師範卒 & $\begin{array}{r}149 \\
(93.6)\end{array}$ & $(0.6)^{1}$ & $(1.9)^{3}$ & $(0.6)^{1}$ & $(0.6)^{1}$ & ( $\left.3.8^{6}\right)$ & $(1 .)^{2}$ & $(1.3)^{2}$ & $\begin{array}{r}159 \\
(100.0)\end{array}$ \\
\hline
\end{tabular}

（注）「その他の私大卒」は、京浜地方の私立大学・高専のみ 
第 5 表 私大卒業生の職業

\begin{tabular}{|c|c|c|}
\hline 職 業 在隹地域 & 県 内 & 県 外 \\
\hline $\begin{array}{l}\text { 大学 教 授 } \\
\text { 中学高校教員 }\end{array}$ & $\begin{array}{r}\left(\begin{array}{r}1 \\
0.6)^{4} \\
(24.6)\end{array}\right.\end{array}$ & 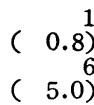 \\
\hline 会 社 員 & $\begin{array}{r}14 \\
(8.3)\end{array}$ & $\begin{array}{r}61 \\
(51.3)\end{array}$ \\
\hline 会社 - 団体役員 & $\begin{array}{r}12 \\
(7.2)\end{array}$ & $(6.7)^{8}$ \\
\hline 官 庁・公 社 & $(1.8)^{3}$ & $\begin{array}{r}16 \\
(13.4)\end{array}$ \\
\hline 県 - 市町村関係 & $\begin{array}{r}15 \\
(9.0)\end{array}$ & $(3.4)^{4}$ \\
\hline 医 & $\begin{array}{r}44 \\
(26.3)\end{array}$ & $\begin{array}{l}4^{4} \\
(3.4)^{2}\end{array}$ \\
\hline 弁 護 士 & $\left.\begin{array}{l}0 \\
(\quad 0\end{array}\right)$ & $(2.5)^{3}$ \\
\hline 自営商工業 & $\begin{array}{r}27 \\
(16.2)\end{array}$ & \\
\hline & ( 4.2$)^{7}$ & \\
\hline そ の 他 & $(1.2)^{2}$ & \\
\hline 不明 & $(0.6)^{1}$ & $\begin{array}{r}14 \\
(11.8)\end{array}$ \\
\hline 計 & $\begin{array}{r}167 \\
(100.0) \\
\end{array}$ & $\begin{array}{r}119 \\
(100.0) \\
\end{array}$ \\
\hline
\end{tabular}

るこ域

第 4 表 旧帝大卒業者の職業

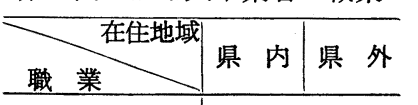

大学 教 授 $(8.4)(14.6)$

高 校 教 員

276

会 社 員

会社・団体役員

官 庁・公 社

県・市町村関係

医

5
$(4.7)(40.7)$

6 ( 15

7.3)

)

0) $(14.1)$

$(11.2)(1.9)^{4}$

師

$(27.2)(9.7)$

)

并護士 $(0.9)(0.5)$

自営商工業

その他

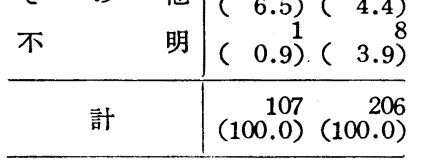

れ移 日 (5)

県 5 動 本

内のとの地

在 卒 の 社 元

住業関会 の

者生連に師

はたでお範

医台、い卒

師のきては

県業めれそ

庁をてぞの

夕特和 ほ

市る徴 のと

町的学え

関第示先 交

係 4 さ果県

・机た内

学 5 、尔定

- 6 るき着

高表之たし

校の思役て

教通わ割い

員でる㤎る。

自あ。地
たが者造みを化例を

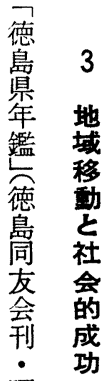

昭

和

四

四

年

所

收

の

人

名
いでをのる資すにみ以 き切なこ料る黾た上

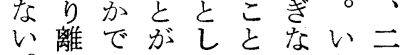

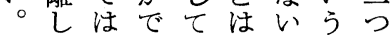
こた、きいで。まの のの低なるきもで学 点で学かのなっも校 には歴っでいとなの つ、者た、。多く同 い学の。初まく、空 て歴地高等たのこ会 注域学教、事こ名 、義移歴育中例に簿 別社動者学等を示を の会との歴教集し用 機の深地所育めたい 会全関移者段て皆み注 実構連動ののなき学 証造を注地学いわ歴 的学棫校とめ別 なとつ一移の地 検らて定動同結限城 討えおのの空果ら移 をるり社動会をれ動 試こ、会向名一た哭 第 6 表 徳島工専卒業者の職業 営

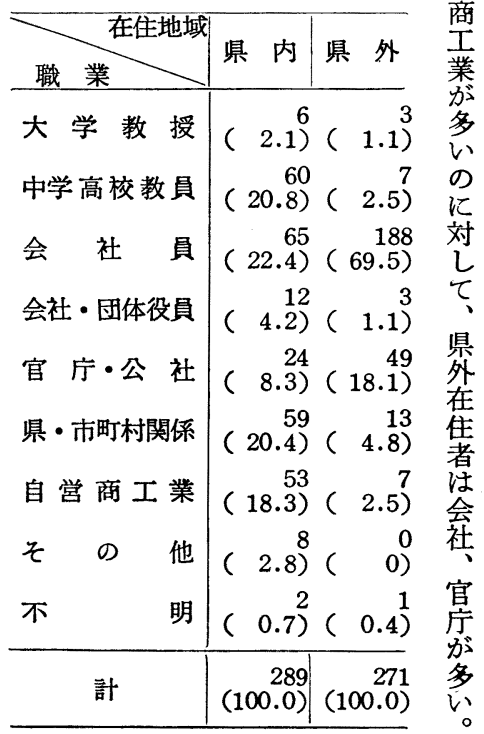


学歴と地域移動

第 7 表 県外在住名士の 移うず四近多以一人てし三得の学録 現住地域

\begin{tabular}{|c|c|c|c|}
\hline \multicolumn{3}{|c|}{ 現住地域 } & 実数 (\%) \\
\hline 四 & & 国 & $53(15.7)$ \\
\hline 京 & 阪 & 神 & $110(32.5)$ \\
\hline 京 & & 浜 & $149(44.1)$ \\
\hline そ & の & 他 & $26(7.7)$ \\
\hline & 計 & & $338(100.0)$ \\
\hline
\end{tabular}

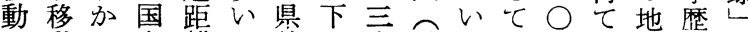
に動七内離の外の人県るお○い域壳に よを・にに注在考で内。り○るでどは つ通七在あ京住察あ出そ、枚か成が、 てし\%住る浜名老る身の昭のを功収徳 注七に京地士行。九内和問知し録島 生生すて阪方のなこ兰訳四合るたさ貝 ままぎい神で現うの三注四わこ人れ在 れれなる在四住 にるい者住四地号、県版にががい名 く边著・域 いの社 - がーを 第8表 県外在住名士の そ市会五兰\% \% 県外でよでどる士 県外在はりきえ。お 学市成七点を

\begin{tabular}{l|r}
\multicolumn{2}{c|}{ 定数 (\%) } \\
\hline 年令 & 令 \\
\hline ～40才 & $16(4.7)$ \\
$41 \sim 50 才$ & $50(14.8)$ \\
$51 \sim 60 才$ & $92(27.2)$ \\
$61 \sim 70 才$ & $117(34.6)$ \\
71 才 & $62(18.4)$ \\
不 明 & $1(0.3)$ \\
\hline \multicolumn{1}{c|}{ 計 } & $338(100.0)$ \\
\hline
\end{tabular}

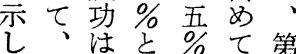
外出住、正るなこよ 在身者二確。学秃び 住一三○苍こ歴に同 者六三仓期の老よ県 严八○し、経っ出

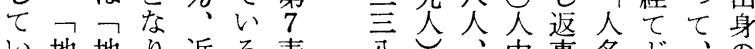

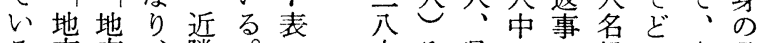
$41 \sim 50$ 才 $50(14.8)$ る方方、隣。の留一の録え出県

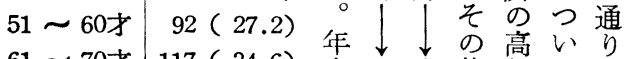
61 〜0才 117 ( 34.6$)$ 令地大他知でで 71才〜 $62(18.4)$ は方都の徳あ の内四あ屯な身外 男他在六っ $っ$ 職地在 二住四た、業域住 に二者人も往上を名 つ人五がの復の離士 い、一回它注地机の て女 $\bigcirc$ 答集が位て職 8 と域松県。 表いと筷な留 のういわどらも 性一乙録き范他榉

第以

表 厽

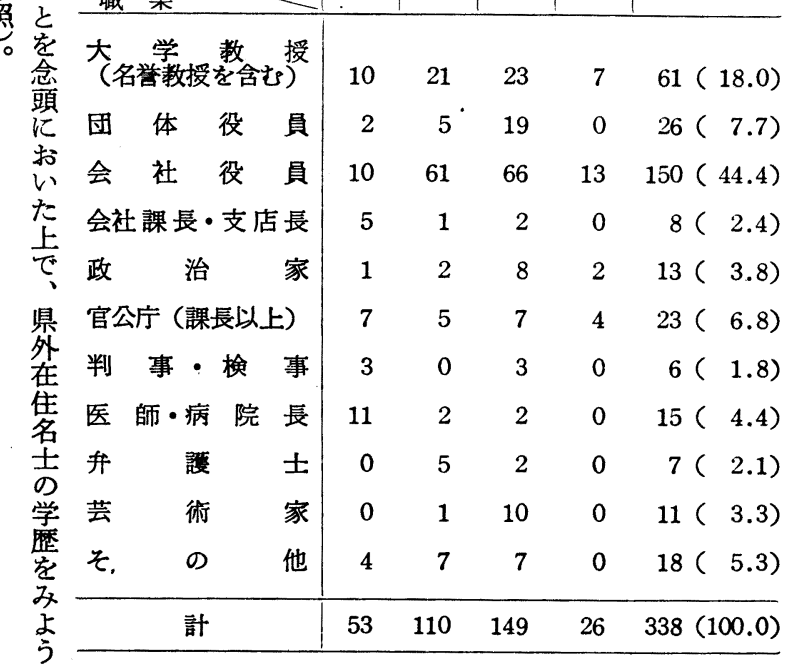
第 9 表 県外在住名士の職業<smiles>[13CH2][13CH2]</smiles>

\section{(1)}

四国 倞阪神 京浜 その他 total

的いがな占よ 
士め 第 10 表 県外在住名士の学歴

\begin{tabular}{|c|c|c|c|c|c|c|c|}
\hline 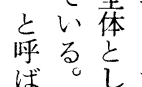 & 学歴 & 四 & 京 阪 神 & 京 & 浜 & そ の 他 & total \\
\hline & 大 & $3(5.7)$ & $5(4.5)$ & 34( & 22.9) & $3(11.5)$ & $45(13.3)$ \\
\hline & 大 & $5(9.4)$ & $21(19.1)$ & 12( & 8.1) & $1(3.9)$ & $39(11.5)$ \\
\hline & 他 の 帝 大 & $6(11.3)$ & $6(5.5)$ & 6( & $4.0)$ & $7(26.9)$ & $25(7.4)$ \\
\hline & 他の官公立大 & $9(17.0)$ & $7(6.4)$ & 11( & 7.4) & $0(\quad 0)$ & $27(8.0)$ \\
\hline & 外 国 大 & $0\left(\begin{array}{ll}0 & 0\end{array}\right)$ & $0\left(\begin{array}{ll}0 & 0\end{array}\right)$ & 2( & 1.3) & 0( & $2(0.6)$ \\
\hline & 私立大学高専 & $5(9.4)$ & $22(20.0)$ & 31( & 20.8) & $4(15.4)$ & $62(18.3)$ \\
\hline & 官 立 高 専 & $7(13.2)$ & $11(10.0)$ & 14( & 9.4) & $3(11.5)$ & $35(10.4)$ \\
\hline & 陸 士・海 兵 & $0(\quad 0)$ & $0(\quad 0)$ & 2( & 1.3) & $0(\quad 0)$ & $2(0.6)$ \\
\hline & 美 校・音 校 & 0( & 0( & 6( & $4.0)$ & 0( & $6(1.8)$ \\
\hline & 範 & $1(1.9)$ & $0 c$ & 1( & $0.7)$ & 0( & $2(0.6)$ \\
\hline 鹿 & 中 学·実 業 & $10(18.9)$ & $19(17.3)$ & 14( & 9.4) & $5(19.2)$ & $48(14.2)$ \\
\hline 子 所 & • 高 小 & $3(5.7)$ & $14(12.7)$ & 8( & 5.4) & $2(7.7)$ & $27(8.0)$ \\
\hline & の 他 & $4(7.5)$ & $3(2.7)$ & 6( & $4.0)$ & $0\left(\begin{array}{ll}0 & 0\end{array}\right)$ & $13(3.8)$ \\
\hline & 不 & $0\left(\begin{array}{l}0 \\
0\end{array}\right)$ & $2(1.8)$ & 2( & 1.3) & $1(3.9)$ & $5(1.5)$ \\
\hline & 計 & $53(100.0)$ & $110(100.0)$ & 149( & 100.0) & $26(100.0)$ & $338(100.0)$ \\
\hline
\end{tabular}

0けもしタか会同的みがも中\% や向い高興とがよか 分てのたイら社じ舁る記う小をとやがる専味り必うし 類おがもプ会の会進と載少企占こ多みが卒深わ要なそ でき多のは社な社の、さし業めろいら、がいけ不大の

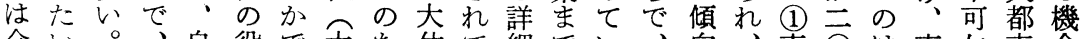
会い。、自役で天ち体て細でい、向、東

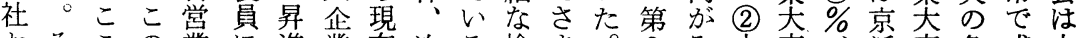
お乙この業に進業在次る検ま。9 9 中卒浜卒条成小 よこでなな横ししののが討ざだ表ら等が官と、件功さ

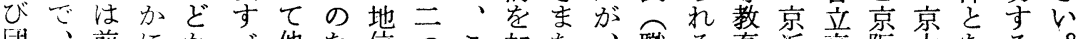
畴、前にか心゙他な位つこ加な、職る充浜高阪泉なる。 体京者はらりのかにの机えも一業っ以地専神卒った今 の浜老各身し会で到夕をての口構し下方卒ののてめ日 役、官種をた社昇達イもみがに成かのの貸間優いに 員京嘹団おもの進しプとる含会比学京二に位るは出

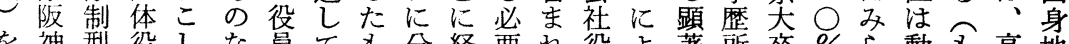
を神型役しな員ても分経要れ役よ著所卒\% \% 動も高地 上地、員てどに役の類営がて員れな有がをれから等域 述方後と独孞横員で賏者あおと潼者京占るしる教を の在者な立含寸にあきたるりいいでは阪め差がえ育流 二住老っのまべなりるちち゚、っ会は京神て異た十学出 つの独て事れりっ、。の人こて社な浜地いでい分歴し の経立知業るしたこ一経名れも役心ょ方るあ。条をて 夕賞息名家。たものつ歴録に、員しりに点る地件獲東

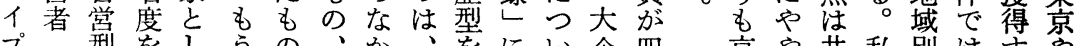
プ型をしうの、か、老にい企四京や共私別は悉や に第々高て二、一に官調はて業四阪多通立になる大

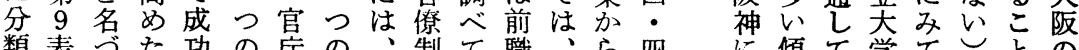
類表うた功の庁の、制て職、ら四に傾て学て学との 
相少少て世大 当ななる主が 数いW誤義果 含あ彼で地乞 れとらは域て てでのあ移き い指学る動た る 摘歴まの役 大る泩い。結割 都が等独㤎き 市、教立こわ へ独育自のめ 移立以営数 動自下型字大 し営がはにき た型多、如く 独壮く官実 立土、僚に東 自着高制あ大 営の学型ら老 型名歴にわパ の土者くれイ 不の注らてプ 利なきべいと なかわてるす 点にめ数とる は注て歹出
な官るべたし ᄀ僚のたいて 中制はとも 央型東このみ 指挂先らはた 向注卒算除な の五あ11たお

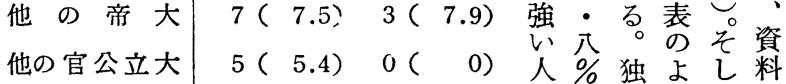
外国大 $1\left(\begin{array}{llll}1.1 & 0 & 0 & 0\end{array}\right.$ 材を立引七 私立大学高専 $18(19.4) 7(18.4)$ 吸め営結 穴收て型果三市

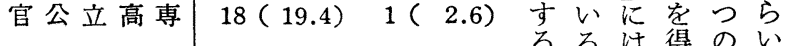
中学・実業 15 ( 16.1$) 13(34.2)$ 上。東た夕ず 小・高小 $2(2.1) 12(31.6)$ で官委。イれ

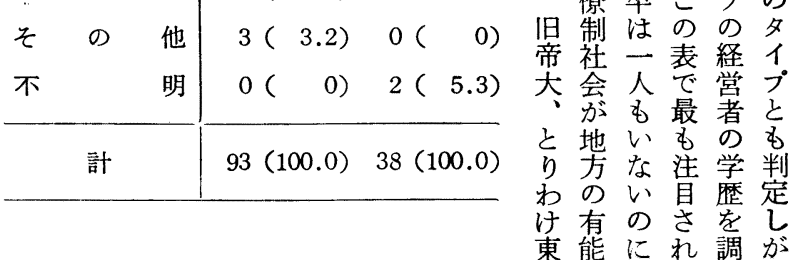

校存商役るから市りが員出出二元在 長在業で。な。町意含、先身人県い住 なと学あこり第村味ま市機者、内る名徳 ぞい校るこ大 12 長がれ町関は県在県士島 高っをこでき表、なて村の会外住内に県 等て卒といくの会いい会長社出名在つ年 教よ柴はう、よ社のる議へ・身士住い鑑 育いしい会高う役で。長二団者名てし 学。たう社等に員、こ一四体二男士み所 歴も者ま役教、に県れ大・役六しとて収 をちがで員育中つ庁ら学五員九は比きの 必乃最子注学等い課の教\%气人、較た、

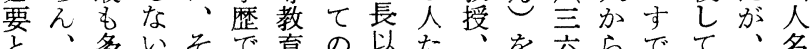

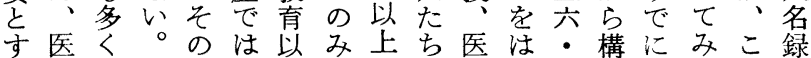
る師、地ほ私下、出の師じ七成述よれし 職、旧元と㚐のそ出学・め\%柋うをを 篻帝のん卒学の先歴病とし机た。同も の護大旧どが歴学閏を院しやてょじと

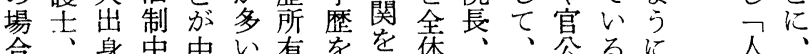

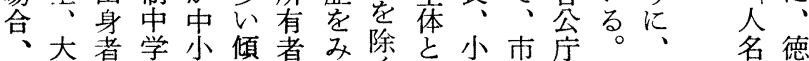
東学泩企向のるこし中町のこ県録島 大教むた業が占こ、て高村課の内罗県 卒授しはの認めと県み校長長う出に出 をるろ工社めるに会て長、補ち、身記身 は高例業長め割に議も之県佐、者載の じ等外学々合し員あの会以県九皆 め学的校重れがよ一他議上内等神
れ心と去

寸強ら省

4 以固注も

となじの

贯考意めな

内志なら

在 らをけ文

れ必れの

る。要ば上 となに

るない がいて 々 そ少く 成こ文 功 $と$ の はでで 多あき 分りる 偶々基 然れを にだ固 左けめ 右冒る さ険こ 
う。歴ろ自県架東央二主 あ持外外み大光 ろ出在 5 卒 う主身住れやつ京帝 分染の名る京な大大 。德県士。兵出出 以島内之卒り三身 下県在の のと五者 、内住比よい人品 県江名較引う、い 外移士と点そな 出入でい特でのい 身しあう定重他わ 者、点学要のけ 六どう空歴な帝で 九などと有喿卒な 人職えく者を三い を業なに比晋。 対上地興よっ人九 象の域味つ県が拲 地考位ら梁年点要 考位ら、心点要要全 察得どは、ら沙て、 行いなるる机、い東 なる学し傾般卒

第12表 県内出身者の職業別学歴

\begin{tabular}{|c|c|c|c|c|}
\hline $\begin{array}{l}\text { 職 業 } \\
\text { 学 歴 }\end{array}$ & $\begin{array}{ll}\text { 県 } & \text { 宁 } \\
\text { 課 長 } \\
\text { 上 }\end{array}$ & 県会議員 & 市町村長 & 会社役員 \\
\hline 大 & 1 & 0 & 1 & 2 \\
\hline 大 & 6 & 1 & 1 & 5 \\
\hline 他 の 帝 大 & 1 & 0 & 0 & 4 \\
\hline 他の官公立大 & 1 & 1 & 1 & 8 \\
\hline 私立大学高専 & 7 & 11 & 5 & 46 \\
\hline 官 立 高 専 & 15 & 3 & 3 & 31 \\
\hline 範 & 1 & 1 & 1 & 7 \\
\hline 学·実 業 & 17 & 11 & 10 & 83 \\
\hline 小 - 高 小 & 9 & 9 & 6 & 28 \\
\hline の 他 & 1 & 3 & 1 & 15 \\
\hline 不 & 0 & 1 & 2 & 45 \\
\hline 計 & 59 & 41 & 31 & 235 \\
\hline
\end{tabular}

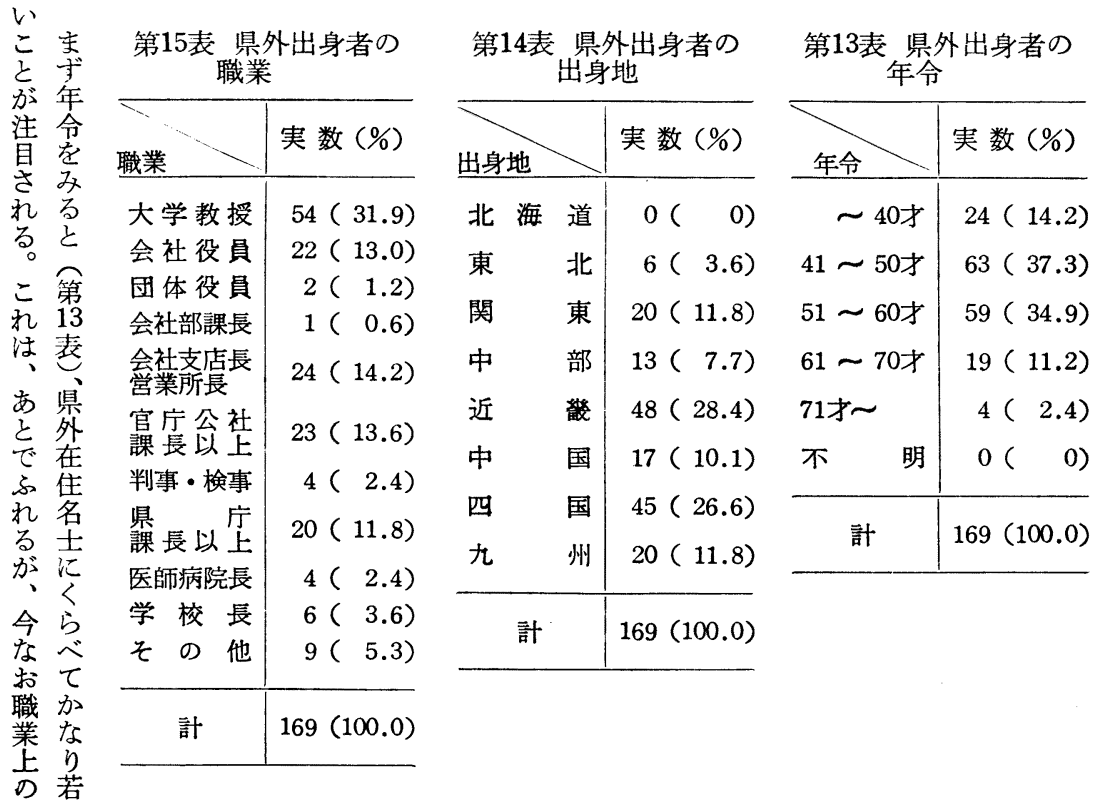


一中に着

人英前しさ

と官職たて

な庁をの

りに調分問

、いべぞ題

德たてう注

島者及们

県是た、他

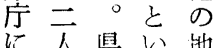

以、梦亏域

前他出こ少

かの身とら

ら県ので移

心序県動

たに庁るし

注た課こき

四者長のた

人点人

に人上をた

す、三た

き公○し㤎

な公人か徳

いにのめ島

○うる県

官者去等
九成考やので度思地 \% 以以古が長会分方域 と、上らてな社散れ移 少第のれまぞ支しる動 数 16 るたが店て。の で表う。他多長い出途 あのなのい。る身上 っよ特地 営 地に てう徵域第業第注亦

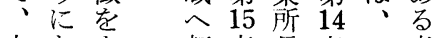
大なる 転表長表四者 部るつ出合。国唯 分。県しこ官職、相 注中外的宁業近当 高等出いな. 第数 等教身く加公注嘼含 教育の流飞社、多宝 育徳動は・大以机 学管型県学がて 歴の県の他庁教、い 所学呙職のの授他る 有歴在業地部孞のた 者所住吕域課最地め で有名かか長子域で あ者士なら・多には るはの り転出くもな 一学市入先市い 一摩方し機つるか
18 東々学割庁店考着

表卒七磨を演本長觉型德 の送注等社官和県 演り注るか庁る想呙 ず込自から・地に 要专学送公地移 役当論方社を域入 割て必し込の 方々 がい要る要課流転

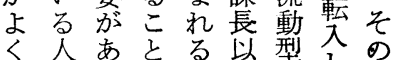
示たる注人型市後

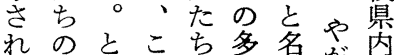

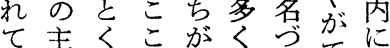
い流にで当はけて定 るが中の該つる着

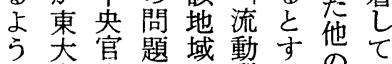
に卒庁でに型れ地い 思でかはお地る わ市ないで、或も れる県いていると転を る。部彼な中会夺移

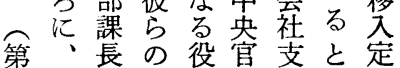

第17表 前職時の在住地域 て名在地社

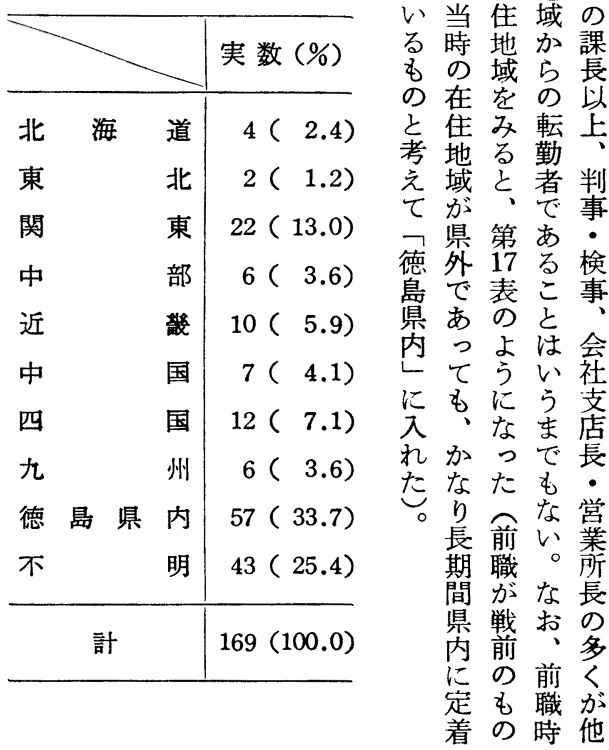




\begin{tabular}{|c|c|c|c|c|c|c|c|}
\hline \multirow{2}{*}{ 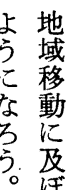 } & \multirow{4}{*}{$\begin{array}{l}5 \\
\text { 要 } \\
\text { 約 }\end{array}$} & \multicolumn{6}{|c|}{ 第18表 県外出身者の職業別学歴 } \\
\hline & & 学 歴 & 会店祳 & $\mid$\begin{tabular}{c|} 
官庁.公社 \\
課長以上
\end{tabular} & $\begin{array}{l}\text { 県 } \\
\text { 課長以上 }\end{array}$ & 大学教授 & $\begin{array}{l}\text { 団体役員 } \\
\text { 会社役買 }\end{array}$ \\
\hline 。底わ & & 大 & 0 & 2 & 9 & 6 & 0 \\
\hline g & & 大 & 2 & 3 & 2 & 12 & 1 \\
\hline 響 & & 他 の 帝 大 & 0 & 2 & 3 & 13 & 1 \\
\hline 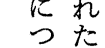 & & 他の官公立大 & 2 & 0 & 0 & 13 & 2 \\
\hline い資 & & 私立大学高専 & 9 & 2 & 3 & 3 & 9 \\
\hline 検に & & 官 立 高 専 & 4 & 5 & 2 & 4 & 1 \\
\hline L & & 陸 土・海 兵 & 0 & 2 & 0 & 0 & 0 \\
\hline $\begin{array}{l}\tau \\
き い\end{array}$ & & 美 校・音 校 & 0 & 0 & 0 & 3 & 1 \\
\hline た て & & 中 学·実 業 & 4 & 6 & 1 & 0 & 6 \\
\hline 要 は & & 小 - 高 小 & 0 & 0 & 0 & 0 & 2 \\
\hline す る & & の 他 & 1 & 2 & 0 & 0 & 0 \\
\hline $\begin{array}{l}\text { れが } \\
\text { ば }\end{array}$ & & 不 & 2 & 3 & 0 & 0 & 2 \\
\hline 次歴 & & 計 & 24 & 27 & 20 & 54 & 24 \\
\hline
\end{tabular}

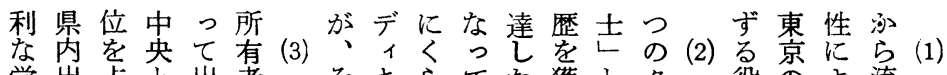
学出占と出者々 歴身めの身が出の十心゙いも得呼イ地割私っ出一 所者てつ地い身成ッてるのしばプ方に大て高般

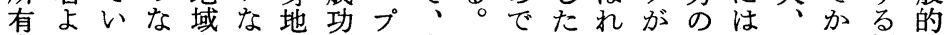
者りるが内い域注が土大あのうあ出差地な傾に には者りにわに偶あ台都るちるる身異元り向い よむがと定けと然りゔ市。、地。地がの差がっ つしいい着でぞ的、くにこ主位一域あ工兾みて てろるうしはまなそり移のとをつをる専がら、 占中こ点てなる千れか動調し獲は離。等あれ高

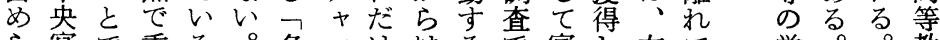
ら官で重る。名ンけはるで官し有て学。教 れ庁あ要が彼士不冒じ独は僚た利大校ます弆

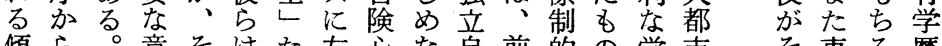
傾ら。意々はた左心な自前的の学市々東ろ歴

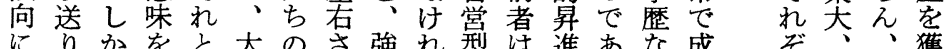
にりかをと大のさ強れ型は進あな成をそ獲

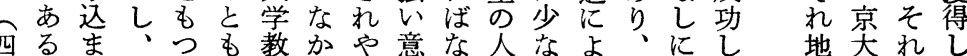
国。れそ県に授にす壳ら物くっ他上た域、はた

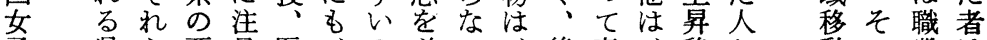
子県 ら要目医、の必い、後高、移た 大外の職さ師有で要と土者い高動ち 学出地なれな利あ要い着㤎地等しに対の地出 身位どるどなろとうの優位漖ては注域身

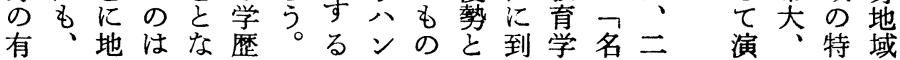




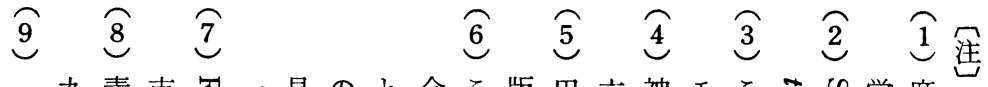

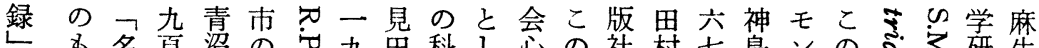
に

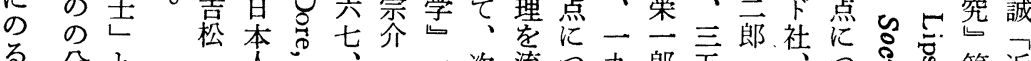

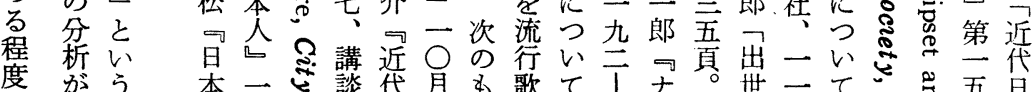

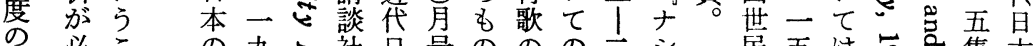

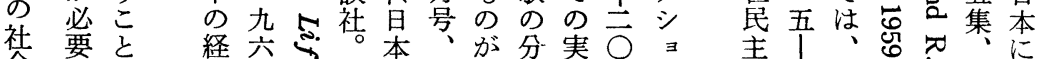

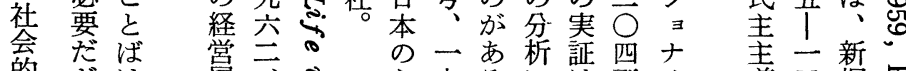

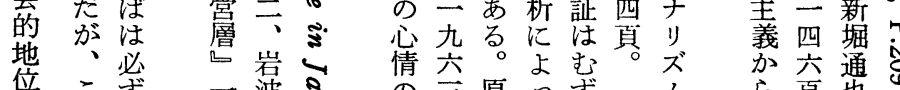

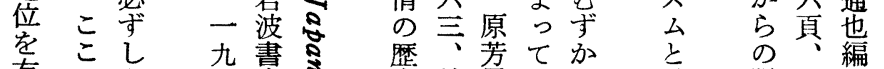

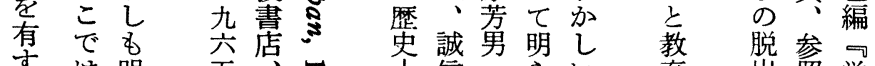

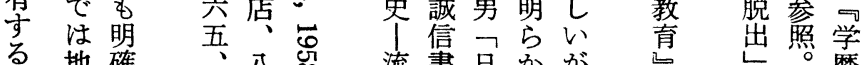

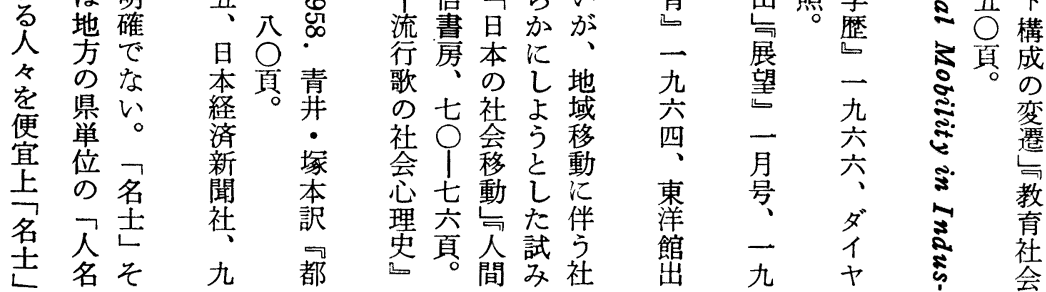

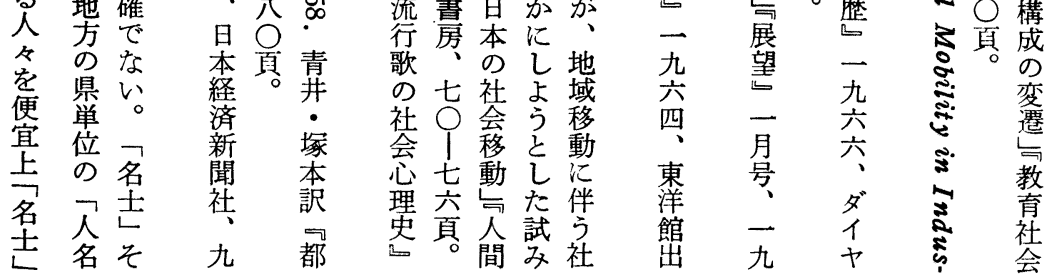


establishment (Oyake).

At about the same time, Shusse was divided into two kinds. One was the substantial Shusse, which was to gain high position, wealth, and prestige. The other was the ideal Shusse, which meant the acquisition of admiration from the person at the highest position (Emperor in Japan) without gaining substantial value.

(3) And, Rissin-Shusse-ism functioned as a main drive to develop industry in Japan, as the protestant ethics had driven capitalism in Europe.

Next, I verified some hypotheses by analyzing the historical data. As a result of the analysis, I found that after about the middle of Meiji period, the conception Risshin and Shusse changed gradually, and near the end of Meiji, the two concepts came to have the same meaning, that is, upward mobility of status without self-realization.

\section{School Career and Migration}

\section{Akira Harada (Shikoku Women's College)}

This report deals with the relationship of school career to migration from local areas to metropolitan areas. It consists of two parts. One is to investigate the extent to which people's migration from their communittes of orientation to other areas are influenced by educational background. The other is to analyze the occupations and school careers of successful men from a particular area.

The materials used in this research are lists of graduates of two middle schools in Tokushima Prefecture and a Who's-Who printed jn “Tokushima Ken Nenkan" (the Tokushima Prefecture Year Book, 1969).

The findings are as follows:

1) Generally speaking, people with higher education who grew up in local areas tend to leave their communities to go to big cities.

2) Among people with higher education who grew up in Tokushima Prefecture, a graduate of highly selective national school such as the Tokyo Univerity is more likely to leave his home prefecture than is a graduate of an unselective private university.

3) About $44 \%$ of successful men from Tokushima Prefecture live in TolkyoYokohama District and 33\% in Kyoto-Osaka-Kobe district; $78 \%$ of them are highly-educated migrants. 
4) Businessmen from local areas are divided into two types: a selfmade man and a highly educated migrant who reached a high position within the bureaucratic organization like a government office or a big enterprise. The latter is more successful than the former.

\title{
A Study of the Conditions Determining Quitting and Staying in Office of Women Teachers
}

\author{
Masashi Fukaya \\ (Nara Teacher's College) \\ Kazuko Fukaya \\ (Tokyo University of Education)
}

Aim: Today in Japan, it is said that the percentage of women who keep on sticking to their post is rather low; this is even true with women who try to get professional jobs after graduating from college as well as those who try to get clerical jobs or jobs related to service after leaving school This is due to such circumstances as marriage, delivery, and childcare. As a matter of course, reasonable systems and institutions should be considered for protecting working women. But under the existing circumstances, almost all the women have been working under unfavorable conditions. Then what kinds of individual conditions are contributing to the retirement or continued service of women ? We investigated on women teachers who are considered to be enjoying the most advantageous and stabilized status among all women workers.

Purpose of investigation and its method: 604 women who graduated from Nara Teacher's College under the new system were selected by randomsampling. Printed questionnaires were sent to them and after a little while were sent back. Fifty-five per cent of them were collected. The survey was conducted in January 1968.

Result: (1) Sixty-six per cent of examinees were married; 46 per cent of the graduates married within three years after they entered teaching profession. Moreover, 86 per cent of them had first child within two years after marriage; 57 per cent of their husbands were teachers; and if other workers, such as public servants and salaried men; 90 per cent of all their husbands were whitecollar workers including public officials and other salaried men as well as teachers. That is, "the teaching profession" may safely be said to be rather advantageous 